\title{
Trade Unionism on Academic Performance and Development of Nigerian Universities: A Comparative Study
}

\author{
Marcus Garvey Orji ${ }^{1}$, Kabiru Jinjiri Ringim ${ }^{1}$, Solomon Abba Boman ${ }^{1}$, Akhimien Emmanuel ${ }^{2}$ \\ ${ }^{1}$ Department of Business Administration, Faculty of Administration, Ahmadu Bello University, Zaria, Nigeria \\ ${ }^{2}$ Department of Business Administration, Igbinedion University, Okada, Nigeria
}

Email address:

marcusorji@gmail.com (M. G. Orji), kabirujinjiri@yahoo.com (K. J. Ringim)

\section{To cite this article:}

Marcus Garvey Orji, Kabiru Jinjiri Ringim, Solomon Abba Boman, Akhimien Emmanuel. Trade Unionism on Academic Performance and Development of Nigerian Universities: A Comparative Study. Journal of World Economic Research. Vol. 5, No. 6, 2016, pp. 91-100. doi: $10.11648 /$ j.jwer.20160506.11

Received: June 29, 2015; Accepted: July 9, 2015; Published: February 24, 2017

\begin{abstract}
Labour disputes have become regular occurrences in Nigeria and the right to trade unionism has been constantly abused. Such unionism abuses and disputes often results in low productivity, which in turn affects the demand and supply chain of the economy. The laws in the country are always not abided by, so rather than bargaining, unions embark on strike as first resort, thereby constantly disrupting industrial harmony and academic activities in Nigerian Universities. The objective of this study is to make a comparative assessment of both Nigerian Private and Governments owned Universities and determine whether there is any relationship between non trade unionism and industrial peace, academic performance and productivity in these institutions. The study is a descriptive research designed in line with empiricism case study, and secondary data were mainly applied and were analysed by content analysis. The findings of the study revealed that There is a significant relationship between non trade unionism and industrial peace, academic performances, productivity and development of Nigerian Private Universities unlike the Government owned Universities; and that unionism in Nigerian private universities don't disrupt students academic activities, which enhances student's performance. The study draws its conclusion on the fact that regulated or Non trade unionism will always result to industrial peace which is necessary for high academic performance and productivity in Nigerian Universities, and therefore recommends that even though the right of association is a fundamental one, private universities in Nigeria should continue to recognize staff associations but such associations should be regulated and should not be allowed to join the national unions to avoid incessant strike actions; also Labour management dispute committees should be established in all Nigerian universities to handle all union matters internally to further increase productivity.
\end{abstract}

Keywords: Trade Unionism, Academic Performance, Development, Nigerian Universities

\section{Introduction}

Trade unions have become important agent of socioeconomic transformation and class struggle. In Nigeria, life before the advent of colonialism particularly the economic aspect did not call for trade unionism. This was because the Nigerian pre-colonial society operated entirely on the basis of communal efforts. With the emergence of trade unionism in Nigeria and other parts of Africa, the British Colonial Government was forced to take some interest in trade unionism and recognized it as a force to reckon with
(Abdullahi, 2001). And it has continuously been a force to reckon with especially in our Universities.

A trade union, also called, labour union is an organization of workers who have banded together to achieve common goals such as protecting the integrity of its trade, achieving higher pay, increasing the number of employees an employer hires, and better working conditions. The trade union, through its leadership, bargains with the employer on behalf of union members and negotiates labour contracts (collective bargaining) with employers. The most common purpose of these associations or unions is "maintaining or improving the 
conditions of their employment. This may include the negotiation of wages, work rules, complaint procedures, rules governing hiring, firing and promotion of workers, benefits, workplace safety and policies. Unions may organize a particular section of skilled workers (craft unionism), a crosssection of workers from various trades (general unionism), or attempt to organize all workers within a particular industry (industrial unionism). The agreements negotiated by a union are binding on the rank and file members and the employer and in some cases on other non-member workers. Trade unions traditionally have a constitution which details the governance of their bargaining unit and also have governance at various levels of government depending on the industry that binds them legally to their negotiations and functioning.

In the eye of the law, what constitutes a trade union may vary from country to country. In Nigeria, the first trade union law entitled 'The trade union Ordinances of 1938" defined a trade union as-

'Any combination whether temporary or permanent, the principal purpose of which are the regulation of relation between workmen and workmen, or between masters and masters whether such combination would or would not if this ordinance have not come into effect been deemed to have unlawfully combination by reason of someone or more of its purpose being in restrain of trade"

This was further clarified by section 1(i) of the Trade Union Act 1973, which stated that a trade union is;

'Any combination of workers or employers, whether temporary or permanent, the purpose of which is to regulate the terms and conditions of employment of workers whether the combination in question would or would not, apart from the Act, be an unlawful combination of reason of any of its purpose being in restraint of trade, and whether its purposes do not include the provision of benefits for its members"

Many questions have been asked as to the role of trade unions. A number of such roles can be identified. First, is to improve the bargaining strength of the workers vis a vis the employer. This is achievable through regular consultation with the employer and management on issues relating to the terms of employment and general working condition of the workers. Secondly, is to protect workers from humiliating job especially with regards to the treatment of workers by the management. Trade unions achieve this goal through rising to the defense of the workers whenever management policy tends to degrade their condition. Thirdly, the unions provide collective identity to workers while at the same time representing a forum of collective bargaining for workers. Fourthly, trade union act to influence government on programmes concerning workers. As workers representatives, trade union becomes a virile pressure group in advancing the interests of members both within the workplace and in the larger society. Lastly, trade union perform social objective in cooperating with other elements of the society in promoting social and economic development and advancement of the community. Sometimes in Nigeria trade unions were in the forefront in the struggle against unpopular government policies such as deregulation of the oil sector, retrenchment of workers and refusal to honour agreement on wage increase, which the authorities considers as antagonistic. It is this assumption that has made many private organizations or institutions to disallow their employees from being part of registered trade union membership in Nigeria. Since the liberalization of University education in 1998, there is none of the licensed private universities that have allowed their academic and non academic staff to join the various national unions such as Academic Staff Union of Universities (ASUU), Senior Staff Associations of Nigerian Universities (SSANU) or others. It is in the light of this that this study intends to assess the right to trade unionism in the Nigerian Private Universities and how this has affected industrial peace, productivity and academic performance.

\subsection{Statement of the Problems}

The existence and maintenance of right to trade unionism in Nigerian Private Universities will provoke many questions, such as; will it support or retard the progress of private universities? Secondly, will unionism undermine or support productivity and academic performance. These questions are very pertinent considering the fact that labour disputes have become regular occurrences in Nigeria, and the right to trade unionism has been constantly abused. Such unionism abuses and disputes often results in low productivity, which in turn affects the demand and supply chain of the economy. The laws in the country are always not abided by, so rather than bargaining, unions embark on strike as first resort (Mainasara, 2009), thereby constantly disrupting industrial harmony and academic activities in Nigerian Universities. Within the last two decade, labourmanagement disputes have become the hallmark of virtually all labour unions in Nigeria. These disputes have resulted in several strikes, weakening the socio-economic fabrics of the country. In fact it may not be exaggeration to assert that there was no single day that passed in Nigeria within the last ten years that one union or the other was not on strike. The cost of strike to the union and its members is believed to represent loss of income, in addition to social cost, represented by the bad image which it imposes on them. While on the employer's side, the costs are in terms of lost output and profit. For the economy, loss in productivity, which affect the Gross Domestic Product (GDP). Non-trade unionism may result to industrial peace which is necessary for high productivity, and development of Private Universities.

\subsection{Research Questions}

On the whole, this study will provide answer to some pertinent questions such as;

i. Is there any relationship between non trade unionism and industrial peace in Nigerian Private Universities, in comparism to Public Universities?

ii. Is there any relationship between non trade unionism and productivity and academic performance in Nigerian Private Universities, in comparism to Public 
Universities?

iii.Is there any relationship between non trade unionism and progress and development of Nigerian Private Universities?

\subsection{Objectives of the Study}

The major objective of this study is to assess the effect of trade unionism on the academic performance and productivity of the Nigerian Private universities in comparism to Public Universities. To achieve this, the following secondary objectives will also be considered;

i. To determine whether there is any relationship between non trade unionism and industrial peace in Nigerian Private Universities, in comparism to Public Universities.

ii. To determine whether there is any relationship between non trade unionism and productivity and academic performance in Nigerian Private Universities, in Comparism to Public Universities.

iii. To determine whether there is any relationship between non trade unionism and progress and development of Nigerian Private Universities, in comparism to Public Universities.

\subsection{Scope of the Study}

This study is specifically concerned on the effect of trade unionism and non trade unionism on industrial peace, productivity of employees and academic performance in Nigerian Private Universities in comparism with Public Universities. The study will focus on two private Universities; Madonna University Elele. and Igbinedion University Okada which are among the first licensed private universities in Nigeria, and two Public Universities-Ahmadu Bello University Zaria, and University of Ilorin.

\section{Literature Review}

\subsection{Conceptual Framework of Trade Unions}

The One of the earliest known attempts to define a trade union is that contained in the Trade Union Act Of 1913 which defines a trade union as:

'Any combination, temporary or permanent, under the constitution Of which the principal objectives are: the regulation of the relations between workmen and workmen, masters and workmen, or masters and masters, or the imposing of restrictive conditions on the Conduct Of any trade union or business".

This definition derives from official statutes or laws of the British Government and this officially confers a legal status in trade unions in Britain. Sidney and Beatrice Webb (1920) define a trade union as a "continuous association of wage earners for the purpose of their working life." The International Labour Organization (ILO) defines a trade union organization as:

'An organization of employees usually associated beyond the confines of one enterprise, established for protecting or improving through collective action, the economic and Social status of its members'

However, a particular definition depends on the perception of workers and the definition imposed by legal framework of a particular country. According to Mainasara (2009) the exact definitions of trade union may vary from one situation to another depending on the economic and political situation encompassing the worker-management relations. The Nigerian Labour Law defines the concept as,

'Any combination whether temporary or permanent, the principal objectives of which under its constitution are the regulation of the relations between workmen and workmen or between masters and masters or the imposing of restrictive condition on the conduct of any trade or business and the provision of benefit to members (cited in Fajana, 1995: 132).

This definition would be seen to incorporate a large variety of organizations and groups under trade union. Another definition of the concept regards it as,

'An association of wage or salary earners formed with the object of safe guarding and improving the wage and employment conditions of its members and to raise members' social status and standards of living in the community (Fajana, 1995).

The preceding definition emphasizes on the purchase of labour power as a factor of production. Trade union is here differentiated from other organizations or associations by the emphasis on the pursuit of better improved condition of service for members. Sidney and Beatrice Webb (1920) further offer the following definitions of trade union:

'A continuous association of wage earners for the purpose of maintaining or improving the condition of their working lives'

This definition emphasizes the dynamic essence of trade union being a continuous association of wage earners. However, it may be seen as too narrow since trade unions are not merely concerned with the improvement of working condition. Beanc (1985) maintained that trade union is best described as institutional representation of workers interest both within the labour movement and in wider society and they accentuate the collective rather than the individual power resources of employers. The radical school of thought gives a contrasting definition of the concept. Trade union is defined as the conveyor belt of the workers desire to put an end to wage slavery and radically transform the society (Hyman, 1971; cited in Mainasara 2009)). This definition conceives trade union as representing the means of actualizing the impeding working class revolution which in the Marxian thought is inevitable in every capitalist society. The various definitions provided here reflect on the role of trade union in the society which include among others; checking the excesses of employers; forum for actualizing the revolutionary potential of labour; defend members' interest against management action or misdeeds; resistance against capitalist domination; providing an opportunity for workers to be equal partners to management; providing workers with a measure of collective strength; vehicle of revolutionary social change. 
Having identified some useful definitions of a trade union, what then constitute the main objectives of the labour unions? Samuel Gompers (1850-1924) provided us with some useful hints: To protect workers in their inalienable rights to a higher and Better life; to protect them not only as equals before the law, But also in their liberties as men, as workers, and as citizens; To overcome and conquer prejudices and antagonisms- the Glorious mission of the trade unions. This definition of Samuel Gompers, the longest serving president of the American Federation of Labour (AFL), is in line with our opinion. At any rate, the leadership of the labour unions does carry the heavy burden of piloting the affairs of the organization and at the same time engage the governmental authorities in matters relating to salaries and wages, better conditions of work and the general wellbeing of the workforce, amongst other responsibilities, as often does by the Academic Staff Union of Nigerian Universities.

Theoretical Framework

We are adopting the class theory and structural functionalism theory of trade unionism as a basis to understanding how it influences the right to of workers in public and private universities in Nigeria. Marx's class theory would enable us to understand organizational structure from the point of view of class societies. Marx (1978) is of the opinion that societal institutions are shaped by economic factors. Thus, economic determinism is the basic feature of capitalist societies. Hence, from Marxian point of view, the structure of organization may reflect class relations or in a way the structural characteristics of capitalist societies, and we know that private universities in Nigeria are mostly capitalist endavour shaped by economic factors of profit maximization. The structural functionalism theory posits that society is made up of structural components and each of the structures serves a useful function, the functionality of which ultimately leads to the stability, unity and social order of society. The implication of this Parsonian theory in the analysis of trade unions is that, they also play a vital role in ensuring the stable socio-political and economic system in Nigerian private universities; employees freedom of association and welfare therefore being the ultimate social order being strived for by trade unions. This theory is however often criticized for being pro-statusquo meaning that it does not favour change. But while change in terms of freedom and welfare is sought for by trade unions in the context of this private universities staff, this type of change is not a radical one but one that keeps the society within the existing conservative order of pursuit for welfare and development.

\subsection{Emergence of Trade Unionism in Nigeria}

According to Anyim, Ekwuoba and Shonuga (2013), the rise of trade unionism in Nigeria cannot be dissociated from the 17th century Euro-African trade. This trade introduced the money economy which gradually replaced the system of barter and almost simultaneously marked the beginning of paid labour (Adebisi, 2004). Apart from increased demand for employable labour which the trade generated, the gradual presence of the colonial administration and the emergence of other commercial concerns dictated the need for more infrastructures, hence the construction of more roads, bridges, rail lines, ports and military bases. All these increased the pool of employed labour as well as took their tool on Nigerian workers (Ananaba, 1969 in Adebisi, 2011).

According to Fashoyin (1980) one of the first major attempts made by Nigerian Workers to assert their rights was by artisans workmen in the Public Works Department (P.W.D) in 1897 who went on a three day strike to protest the arbitrary change in their hours of work. The action was strongly countered by the then colonial governor who threatened to deal with the striking workers if they continued with their action. The workers were undaunted and the Governor agreed to negotiate. The history of the trade union movement in Nigeria has been well documented. Its travails and triumphs as well as the potentials and shortcomings have been highlighted by such writers as, Offiong (1983), and Otobo (1986) among others. Available records indicate that the first trade union to emerge was Southern Nigerian Civil Service Union inaugurated on the 19th August, 1912, and subsequently changed to the Nigerian Civil Service Union (N.C.S.U) in 1914 after the amalgamation of the Northern and Southern Protectorates. One major issue addressed by the union was the discrimination between African and European civil servants.

Active trade unionism in Nigeria can be said to begin in the early 1930s, a period which witnessed persistent workers agitation and restiveness spear-headed by the more radical railway workers who severed their membership of NCSU and formed the Railway Workers Union (R.W.U) in 1931, the major arguments against the NCSU were that it was too softspoken and unresponsive to the economic hardship. In 1938, Trade Union Ordinance, which formally legalized trade unionism and made for compulsory registration of unions in Nigeria was enacted. The law made it unlawful for any union to engage in collective bargaining or embark on industrial action without registration under its provisions. Reasons for the enactment of this law cannot be unconnected with the series of riots, strikes and rebellions that plagued the British Colonies in West Indies and Northern Rhodesia first in 1933 and again in 1937, coupled with the general restiveness of workers occasioned by the hardships they had to contend with ((Anyim etal, 2013)).

Also Pitan (2013) opined that trade unions in Nigeria started as voluntary organizations of workpeople aimed at securing improvements in the wages and working conditions of their members. By 1938, the government persuaded itself or was persuaded to enact a law to regulate the formation and activities of trade unions. It was opposed to the British Common law which impinged on their activities; there was a tacit recognition of the role of the trade unions [the lives of their members and the community] (Joseph, Mire, 1956, in Sonubi, 1987). In 1938, the trade unions showed interest in the wages and working conditions of their members including successful agitation for wage increase in the light 
of the rise in the cost of living after the World War I. The same pressure was kept up during and after the World War II leading to the grant of cost of-living allowance to the workers. However, until recently, the trade unions were too weak and divided to make any appreciable impact on the lives of their members. By 1978, the trade unions were transformed into organizations of employees and employers, aimed at protecting the interests of their members. The selfemployed artisans were dropped by the wayside. The voluntary principle underlining membership was modified in the following ways. Firstly, the intent of policy is that all employees should belong to one trade union or the other, but any employee is free to opt out. Secondly, employees are free to join designated unions, the appropriate unions for their industry or occupation. Thirdly, the 42 National trade unions of junior employees must affiliate to the single, designated, central labour organization. Fourthly, employees designated as projections of management were barred from joining the same union as their subordinates. Thus, although no employee is forced to join or remain in a trade union, the freedom to join or not is subject to the law of the land. Finally, employers and employees cannot join the same trade union. In a more detailed form, the benefits were expressed in the following words: - The union successfully got good collective agreement, for the members throughout the country-Better conditions of service housing allowance, transport allowance, leave allowance and gratuity benefits. Others mentioned better leadership, education of members, same policy throughout the country, more positive responds by managements, greater independence by the union, borrowing from others, recognition by employers, implementation of Onosode Commission report, speaking with one voice, building own secretariat, termination of subcontracts, (which was taking away the jobs of some members), eradication of daily paid system, financial buoyancy for the unions, building of houses for workers by employing and allocating to - even labourers, extension of medical facilities, to ten members of employees' family among others. The benefits to the members, which will be expressed in both personal and collective terms, were attributed to the new trade union's structure. $48.9 \%$, in fact, indicated that their trade unions were participating in socioeconomic projects for the help of the members (Pitan 2013).

\subsection{Emergence of Private Universities in Nigeria}

The belief in the efficacy of education as a powerful instrument of development has led many nations to commit much of their wealth to the establishment of educational institutions at various levels (Okoro \& Okoro, 2014). According to Okoro \& Okoro, (2014), the funds allocated to higher education should not be considered as mere expense, but as a long-term investment. However, despite the enormous human and material resources at the disposal of the Nigeria Government, the Federal Government's investment in education is abysmally very low when and if compared with UNESCO ${ }^{\text {"s }}$ s mandate to all governments of developing nations to invest as much as $26 \%$ of their annual budgetary allocation to education sub-sector. Private universities are a recent development in Nigeria as compared to the federal and state universities. In the $90 \mathrm{~s}$ there was the wind of change of deregulation policy aimed at enhancing active involvement of all stakeholders in the ownership, finance, administration and control of education and thereby making the system more efficient in responding to the learning needs of the society and that of the individuals in a dwindling economy in Africa.

Varghese (2004) claimed that Kenya blazed the trail in the establishment of private higher education institutions in Africa followed by Benin, Senegal, Tanzania, Uganda, Ghana, Mozambique, Cameroon among others. Levy (2003) in his submission however claims that the Francophone African countries lagged behind their Anglophone counterparts in terms of a move towards the establishment of private higher education institutions in Africa. Between 1991 and 1999, about 65 private universities had been established in Sub-Saharan Africa (World Bank 2002).

However, Nigeria's establishment of private higher education has evolved during two historic phases: the first was during the second republic under President Shehu Shagari administration 1979 - 1983 and the second was during the fourth republic under President Olusegun Obasanjo. Some private individual made bold move to establish private universities. Hence, according to Okwori \& Okwori, (2007), the legitimatization of private universities in Nigeria was due to the famous Supreme Court decision in favour of Dr. Basil Ukaegbu, the proprietor of the Imo State Technical University in a case against the Imo State Government that had declared the institution illegal. This singular Supreme Court judgment brought about the establishment of private higher institutions in Nigeria. In 2009, about thirty-two private universities were established.

During this phase necessary machines were put in place to visit and scrutinize applications from individuals, religious and corporate organizations of who are applying for private universities operating license.

Table 1. Trend of Private Universities.

\begin{tabular}{lll}
\hline 1. & Igbinedion University, Okada & 10th May, 1999 \\
2. & Babcock University, Ilishan Remo & 10th May, 1999 \\
3. & Madonna University, Okija & 10th May, 1999 \\
4. & Bowen University, Iwo & 31st July, 2001 \\
5. & Covenant University, Ota & 12th February, 2002 \\
6. & Pan-African University, Lagos & 12th February, 2002 \\
7. & Benson Idahosa University & 12th February, 2002 \\
8. & American University of Nigeria , Yola & 28th May, 2003 \\
9. & Ajayi Crowther University, Oyo & \\
10. & Al-Hikmah University, Ilorin & 7th January, 2005 \\
11. & Bingham UniversityNew Karu & 7th January, 2005 \\
12- & Caritas University, Enugu & 7th January, 2005 \\
13 & CETEP City University, Yaba, Lagos & 7th January, 2005 \\
14. & Katsina University, Katsina & 7th January, 2005 \\
15. & Redeemer's University, Mowe & 7th January, 2005 \\
16. & City University, Ibadan & 9th June, 2005 \\
17. & Bells University of Technology, Badagry & 9th June, 2005 \\
19. & Wukari Jubilee University, Wukari & 9th June, 2005 \\
20. & Crescent University, Abeokuta & 9th June, 2005 \\
21. & Novena University, Ogume & 9th June, 2005 \\
\hline
\end{tabular}




\begin{tabular}{|c|c|c|}
\hline 22. & Renaissance University, Enugu & 9th June, 2005 \\
\hline 23. & University of Mkar, Mkar & 9th June, 2005 \\
\hline 24. & $\begin{array}{l}\text { Joseph Ayo Babalola University, Ikeji- } \\
\text { Arakeji }\end{array}$ & March 2006 \\
\hline 26. & Fountain University, Osogbo & 17th May, 2007 \\
\hline 27. & Obong University, Obong Ntak & 17th May, 2007 \\
\hline 28. & Salem University, Lokoja & 17th May, 2007 \\
\hline 29. & Tansian University, Oba, Anambra State & 17th May, 2007 \\
\hline 30 . & Veritas University, Abuja & 17th May, 2007 \\
\hline 31. & Wesley Univ. of Science \& Tech, Ondo & 17th May, 2007 \\
\hline 32. & Western Delta Univ., Oghara, Delta State & 17th May, 2007 \\
\hline 33. & Achievers University, Owo, Ondo State & 11th December, 2007 \\
\hline 34. & $\begin{array}{l}\text { African Univ. of Science \&Technology, } \\
\text { Abuja }\end{array}$ & 11th December, 2007 \\
\hline 35. & Afe Babalola University,Ado Ekiti & 3rd Novemebr,2009 \\
\hline 36. & $\begin{array}{l}\text { Rhema University,Obeama-Asa, Rivers } \\
\text { State }\end{array}$ & 3rd November, 2009 \\
\hline 37. & $\begin{array}{l}\text { Nigerian-Turkish Nile International } \\
\text { University, Abuja }\end{array}$ & 3rd November, 2009 \\
\hline 38. & $\begin{array}{l}\text { Oduduwa University, Ipetumoda-Osun } \\
\text { State }\end{array}$ & 3rd November, 2009 \\
\hline 39. & $\begin{array}{l}\text { Wellspring University,Evboubanosa,Edo } \\
\text { Sate }\end{array}$ & 3rd November, 2009 \\
\hline 40. & Paul University, Awka-Anambra State & 3rd November, 2009 \\
\hline 41. & Godfrey Okoye University, Enugu State & 3rd November, 2009 \\
\hline 42. & Adeleke University, Ede, Osun State & 7th March, 2011 \\
\hline 43. & Baze University, Abuja & 7th March, 2011 \\
\hline 44. & $\begin{array}{l}\text { Landmark University, Omu-Aran, Kwara } \\
\text { State }\end{array}$ & 7th March, 2011 \\
\hline 45. & $\begin{array}{l}\text { Samuel Adegboyega University, Ogwa, } \\
\text { Edo State }\end{array}$ & 7th March, 2011 \\
\hline 46. & Evangel University, Akaeze, Ebonyi State & 22nd February, 2012 \\
\hline 47. & $\begin{array}{l}\text { Elizade Unıversity, llara-Mokın, Ondo } \\
\text { State }\end{array}$ & 22nd February, 2012 \\
\hline 48. & Gregory University, Uturu, Abia State & 22nd February, 2012 \\
\hline 49. & $\begin{array}{l}\text { Mcpherson University, Seriki Sotayo, } \\
\text { Ajebo, Ogun State }\end{array}$ & 22nd February, 2012 \\
\hline
\end{tabular}

Source; Okoro \& Okoro, (2014).

\subsection{Justification for the Establishment of Private Universities in Nigeria}

According to NUC (2004), the establishment of private tertiary institutions is justifiable because of the numerous benefits accrued to it. Some of its benefits are:

\subsubsection{Provision of Enough and Adequate Teaching and Learning Materials}

Most universities in the country have consistently inadequate resources, which invariably affects the quality of output they produce. Besides, as Utulu (2001) points out, another factor that accounts for the decline in the quality of university output in Nigeria is the lack of physical facilities. The universities in Nigeria operate in adverse conditions; overcrowding and deteriorating physical facilities, lack of library books, educational materials and so on. Addressing this problem calls for the involvement of the private sector.

\subsubsection{Raise Alternative Ways of Funding the University}

Apart from the poor quality of graduates, as a result of poor physical facilities in the federal and state universities, another reason for the involvement of private hands in the provision and maintenance of university education is the underfunding of the education sector. Over the years, this problem has been generating a lot of strife between the ASUU and the government. However, the presence of private hands in university education is considered an alternative means of funding university education in the country. In addition, the provision of technology by the private sector will bring down cost, fasten programme delivery and enhance the capacity of these institutions to reach student in distant places and larger number.

\subsubsection{Improve the Quality of University Education}

The government is of the view that the growth of private universities in the country will allow for competition between the public and the private universities, in terms of instructional delivery and other activities put in place to produce quality graduates for the economy. Competition brings improved quality of educational inputs and outputs.

\subsubsection{Enhance Efficiency}

Internal efficiency in terms of graduating students at record time with very few or no drop-out at all and external efficiency in terms of producing what the market would absorb on graduation to reduce to the barest minimum or eliminate unemployment. Also with more players in the university system, there would be more rational and efficient allocation of resources in the short term. The long-term effect is to stabilize the cost of operation, with an attendant increase in, and improved quality of production. These among others could be responsible for granting of operating license to private universities in Nigeria by National University Commission (NUC).

\subsubsection{Widening Access to Tertiary Education}

In America for instance, the demand for higher education is so high that the gross enrolment ratio is about $100 \%$ while that of Nigeria is $5 \%$, (Adeotomre 2007). What happens to the remaining $95 \%$ ? Following the perennially acute shortage of places in the public universities and the need to increase the number of enrolments, private hands were called upon to create opportunities for the teeming number of youths seeking tertiary education. Hence, the license given to private investors in university education is meant to address the problem of excessive demand over supply. However, access is in this case provided for those who can afford the high fees charged.

\subsubsection{Provision of Stable Academic Calendar}

The varying crises in the university sector, which had been paralyzing the academic calendars over the years constitute a source of worry to the stakeholders in the sector. However, there is need for the establishment of private universities, which are less prone to disruption in their academic calendars. From the foregoing, it can be said that the Nigerian educational system needs private participation in the provision and management of educational institutions, especially at the university level. This is because of the dynamic nature of education, exacerbated by the enormous resources required for the realisation of national goals (Okoro \& Okoro, 2014). 


\section{Methodology}

This study is a descriptive research. Descriptive research is conducted when there are some understandings of the nature of the problem; such research study is use to provide a more specific description of the problem. It has been designed in line with empiricism using case study method. Empiricism in its broadest sense is the habit of explaining universalities from the particulars of experience (Partington, 2002). Thus, we are using two private Universities and two Public Universities particular experiences to explain and understand the universality of trade unionism in the context of Nigerian University's education system and development The sources of information are mainly from secondary data gathered from existing literatures, text books, journals, and other documentary evidences, such as magazines and official publications of the Universities under review. There was also personal interaction between the researchers and some staff of the Universities, and Covert observations, as one of the Researchers has attended some of these schools under study. Content analysis was applied to validate the stated objectives and answer research questions.

\section{Research Analysis and Findings}

\subsection{Comparative Analysis of the Problems of Trade Unionism in Nigerian Universities}

University unions serve a dual purpose. First, the union affords its members a feeling of job security, pursuing cases of unfair dismissal. Second, it provides a forum for members to satisfy psychological needs of belonging, leadership, esteem, etc. The union role in collective negotiation with management enables workers to participate in the management of their organization (Akanwa, 2014). For an organisation to succeed, it must have a healthy working environment. Unions have helped maintain industrial peace, which is needed for achieving institutional goals and providing a strong workforce. But in most institutions of higher learning in Nigeria, however, unions are frequently at loggerheads with management, the government, or themselves, and this is why private Universities owners seems to regulate and sometimes prohibit unionism (Akanwa, 2014).

According to Adedipe (2014) the singular damning problem of Nigerian Universities holistically, the emerging exception of the private universities notwithstanding, is the pains inflicted by way of the unnecessary and paradoxically necessary tussle between the Federal Government of Nigeria and the Academic Staff Union of Universities (ASUU). It need be stated, ab-initio that what obtains with ASUU is also relevant with the other trade unions in the Universities and even in the Polytechnics. The paralysing tussle has become so frequent and so endemic as to constitute a national embarrassment that has cast global doubt on the quality of higher education in Nigeria.

What seems to be in contention is clearly attitudinal. Simply, the Federal Government signed on Agreement and reneges on the implementation of that Agreement by seemingly disowning the agreement, not unmindful of the principle of continuity in governance. In other words, Government is a trustee of the citizens and owes them a respectable level of managing the "assets and liabilities" of preceding administrations. As a consequence, the Government really has no reasonable and respectable choice but to honour that agreement. A sympathetic mechanism or strategy that Government can plead for is a rescheduling of the time -frame for implementation. As for ASUU, and indeed the other Unions, they failed to face the reality of operating with the written and inferential provisions of the University Autonomy Act of 2007, for which ASUU itself fought hard. Having been so instrumental to the enactment, it should also accept the assets and liabilities", the assets being the gains (for example, appointment of Vice Chancellors and the 70 years retiring age of Professors) on the one hand; and the pains (for example the devolution of matters relating to conditions of service to each Governing Council as the employer of all staff). Another pain that the Unions will need to live with according to Adedipe (2014), is the global practice of a good level of sacrifice in the pursuit of future accruals of benefits; in this case, the global best practices of a "strike fund" to mitigate the implementation of "no work, no pay". That is the path of honour in the protection of the hard -earned autonomy. Though the Federal Government itself has not been courageous enough to implement this practice in industrial relations basically because it has not instilled rational allocation of financial resources, based on equity in prioritization, which in any case has impact also on private Universities. It is clear that, with Nigeria's resource endowment, far more than ASUU demands can be accommodated, if the Government gets its priorities right; and given the stark findings of the Government's Needs Assessment Exercise by a Panel consisting of a rainbow Coalition of relevant stakeholders (Adedipe, 2014).

In the past, Nigeria's educational system was the toast of all in the continent of Africa as it boasted one of the oldest, biggest and most comprehensive University Education System. In the 1970s, people of different nationalities moved "en-masse" to acquire qualitative education in Nigeria. But after many years, the story became different as Nigerian Public Universities later became breeding grounds for cultists even as incessant strike actions continued. For instance since the last 10-15 years Ahmadu Bello University Zaria and University of Ilorin has starkly dramatizes the calamities and disruptive consequences of this unruly industrial climate. Starting from the issue of sacked 49 University of Ilorin Lecturers to the real issue of vested interests that is at work in all our federal Universities. Analysis from our covert findings revealed that within five years 2000-2005 there were fourty six (46) union-related activities in Ahmadu Bello University Zaria, made up of short work stoppages, disputes, actual strikes, threat of strikes, rallies, procession, disruption of examinations etc. Of this number seventeen (17) representing $35.5 \%$ were actual strikes. Out of these industrial actions, Academic Staff Union (ASUU) alone was responsible for 35 $(75 \%)$ of the 46 . Furthermore, $37(79 \%)$ of the industrial 
actions were locally directed while $9(21 \%)$ were national. Over 40 cases $(84 \%)$ of industrial disputes were on issues within the competence of the federal Government. Within the same period management and Council of Ahmadu Bello University Zaria instituted disciplinary actions four (4) times (13.5\%) against Union Leaders and enforced Government's directive to withhold salaries only twice. All the strike actions/industrial disputes affected academic activities, but $20(44 \%)$ directly affected the conduct of examinations. All together, about 485 days or sixteen (16) months were lost to industrial action within five years, including total closure of the Ahmadu Bello University for a total of eleven (11) months between December 2002 and March 2004. Where as, since inception of Igbinedion University and Madona University the two Private Universities under our study in 1998, there has never for ones been any disruption of academic activities or closure as a result of any trade union or industrial dispute related activities. Thus, answering our research questions that there is a significant relationship between non-trade unionism and academic performance and development of Private Universities in Nigeria.

\subsection{The Implications of Trade Unions Strikes in Nigerian Universities}

The impact of disruptive academic activities on the Nigerian Federal Universities, their staff, students and host communities has been enormous, unfortunate and costly in terms of monumental losses incurred. Coming down to Ahmadu Bello University for instance, the 2003/2004 session was lost, and the University's over 26,000 undergraduate students lost a year in their studies. Ironically, the same thing happened to 1994/1995 session. In fact between 29th of December 2002 and January 2004, Ahmadu Bello University Zaria received and taught its students for only fourteen (14) weeks. Over 1200 pioneer graduates of the University's School of Basic and Remedial Studies were forced to stay at home for a year until the commencement of the next academic session. The University had over 1300 foreign students from over ten countries then including China, and these students were forced to return to their respective Countries with gloomy memories of disruptions of examinations by some Lecturers in six consecutive semesters in three sessions. The economy of Zaria the host community lost over $40 \%$ of its revenue due to the prolonged closures of Ahmadu Bello University.

\subsection{Factors Influencing Trade Union Strikes in Nigerian Universities}

In as much as Nigerians believe that education should be funded adequately as the bedrock of our national development, the prevailing circumstances points to the fact that some sections of the Nigerian Government owned Universities does not have passion for their jobs, as they think they are only there to get a share of the national cake. Many of them seem not to care about the quality of students they turn out in as much as their salaries and allowances are increased. In other Countries, Universities on their own meager income initiates researches and reach out to corporate organizations for funding, thereby supplementing the funds they received from governments, but Nigerian Government owned Universities are often busy playing ethno-religious politics on who to be Head of departments, Deans, Directors and Vice Chancellors so as to have power to share government allocated funds, at the expense of research. We recognize five major pointers to this tendency of trade union rascality in Nigerian Public Universities as follows;

1. The refusal of trade unions especially Academic staff union (ASUU) to accept and be guided by the principles that every staff is first and foremost an employee, governed by all the conditions there in universities laws, and the procedures by which they are enforced. This refusal is anchored on a new culture of indiscretion and lawlessness, and unionism serves as a legitimate platform for unjustifiably defying and vilifying constituted authority, violating University law, conditions governing employment and resisting any attempt as sustaining order, stability and productivity.

2. The arbitrary actions of a fractions of Nigerian Public University Staff and some unions in the recent past have transformed them into parallel governments and authorities, who manipulate unionism to oppose the reformation of the Universities because they are unwilling to discharge their responsibilities for hardwork, productivity, dedication, vibrant scholarship, respect for the rule of law, accountability and safeguarding the sanctity of the intellectual vocation. Their mission seems to be the creation of an atmosphere of disorder, forcing the Universities into stagnation and violence, or at least creating a situation in which every thing is "business as usual'.

3. Over the years, the idea has crept in that the sole value of unionism in Nigeria is the acquisition and sharing of resources to its individual members and in Nigerian Government owned Universities the assumption has been that the federal government of Nigeria is sitting over huge financial resources and was unwilling to distribute them to motivate universities staff. As a result, a fraction of staff processed to acquire to themselves legally or where this fails through pressure, blackmail, and all sorts of guises, even if this is at the expense of the stability of the Universities. The entrenchment of this tendency constitutes the most patent source of destabilizing the academic system.

4. The ramified interference and the absence of systematic regulatory mechanism for industrial relations and guidelines on membership involvement in the activities of unions, associations, clubs and societies have weakened the abilities of successive Nigerian public Universities Administrations to delineate and enforce responsibilities, rights and privileges in relation to the mission and visions of these Universities and the terms of employment of staff. Thus, it is very difficult to evolve a constructive leadership and sustain a mutually beneficial tradition of scholarship, trust, mutual respect 
and harmony in this circumstance.

5. Also, it appears unionism in Nigerian Public Universities has become and avenue to display radicalism and to seek for cheap popularity, as often times the union leaders are later given government juicy offices and positions.

\section{Conclusions}

Labour disputes have become regular occurrences in Nigeria, and the right to trade unionism has been constantly abused. Such unionism abuses and disputes often results in low productivity, which in turn affects the demand and supply chain of the economy. The laws in the country are always not abided by, so rather than bargaining, unions embark on strike as first resort, thereby constantly disrupting industrial harmony and academic activities in Nigerian Universities. This study draws its conclusion on the fact that regulated or Non trade unionism will always result to industrial peace which is necessary for high productivity in Private Universities.

\section{Recommendations}

Based on the findings from the research work, the following recommendations are made.

1. Even though the right of association is a fundamental one, private universities in Nigeria should continue to recognize staff associations but such associations should be regulated and should not be allowed to join the national unions to avoid incessant strike actions. Because, it is now obvious that the ramified interference and the absence of systematic regulatory mechanism for industrial relations and guidelines on membership involvement in the activities of unions, associations, clubs and societies have weakened the abilities of successive Nigerian public Universities Administrations to delineate and enforce responsibilities, rights and privileges in relation to the mission and visions of these Universities and the terms of employment of staff.

2. Labour management dispute committees should be established in all Nigerian Universities to handle all union matters internally to further increase productivity.

\section{References}

[1] Abdullahi, S. A (2001) 'The development of trade unionism in Nigeria; Achievements and problems. Journal of Business Administration. Vol 1, No 1, p47.

[2] Aborishade, F. (1992). Nigerian Labour Movement in Perspective, Lagos: The Effective Company.

[3] Adebisi, M. A. (2004) "Industrial Conflict and Trade Unionism in Nigeria" Advances In Management" Volume No. 4, Number 1,2004.

[4] Adebisi, M. A (2011) Trade union leadership structure and the challenges of succession politics' presented at the international industrial relations African regional congress holding at the University of lagos, lagos, Nigeria. from january 24th to 28th, 2011.

[5] Adedipe, N. O, (2014), Being Text of the Third Convocation Lecture of the Al-Hikmah University,Ilorin, Nigeria 2014.

[6] Adeniji, M. A., \& Onasote, A. O. (2006). Manpower development programme in Kenneth Dike Library, University of Ibadan. African Journal of Cross Cultural Psychology and Sport Facilitation 8: 80-88.

[7] Adeotomre, J. E. (2007). "Universal Access to Tertiary Education in Nigeria: Issues of Planning" in J. B. Adewumi, F. (2004). Ideological Posturing and Trade Union Leadership in Nigeria (The Story of Comrade Ali Chiroma). Hure Prints, Ibadan.

[8] Akanwa, D. C (2014) Analysis of the Right to Trade Unionism in the Nigerian Private Universities. Unpublished, MA Thesis, Faculty of Law, Ahmadu Bello University, Zaria.

[9] Anyim, C. A, Ekwoaba, J. O ,Shonuga A. O (2013) Industrial Unionism and Its Bargaining Correlates in Nigeria Industrial Relations System' Journal of Management and Strategy Vol. 4, No. 3; 2013 pp 56- 68 Babalola, G. O. Akpa, A. O. Ayeni, \& S. O. Adedeji (Eds). Access, Equity and Quality in Higher Education. NAEAP, Lagos, pp.131-137.

[10] Damachi, U. G. (1978). Theories of management and the executive in the developing world. London: MacMillan. Davison, R. B. (1977). Industrial Relations Decree: Questions and answers to explain the law. Zaria: Ahmadu Bello University Press.

[11] Elaturoti, D. F. (2006). Stakeholders in Nigerian education as facilitators in effective school library service development. Nigerian School Library Journal 5 (2): 57-65.

[12] Esele, P. (2011) Address by the President General of the Trade Union Congress of Nigeria (TUC) at 2011 May day celebrations, held at the Eagle Square, Abuja, May 1st.

[13] Fajana, S. (1995). Industrial relations practice in Nigeria. Lagos: Labofin and Company.

[14] Fashoyin, T. (1980). Industrial Relations in Nigeria. Longman, Nigeria Press.

[15] Fashoyin, T. (1981). Industrial relations and the political process in Nigeria. Geneva: International Institute for Labour Studies. Research Series, (69): 14-16.

[16] Fashoyin, T. (1902). A model of union behaviour in Africa. Lagos: Department of Industrial Relations and Personnel Management.

[17] Iyayi, F. (2002). The principle of our union: First ASUU preNDC lecture delivered at the 12th National Delegates Conference in Maidugri, 5th-8th April, 2002.

[18] Joseph, M (1956), Labour Education: a study report on needs, programmes and approaches. Inter- University Labour Education Committee. p.17.

[19] Imoisili, C. I (1996) "Social research methods for Nigerian students" Malthouse press Ltd. Lagos.

[20] Levy, D. (2003): Profits and Practicality: How South Africa Epitomizes the Global Surge in Commercial Private Higher Education. Working Paper No. 4, PROPHE, State University of New York, Albany. 
[21] Mainasara, I. K. U (2009) An appraisal of trade Unions and employment Regulations under the Law; A case study of Nigerian Labour Congress. Unpublished, LLM Thesis, Faculty of Law, Ahmadu Bello University, Zaria.

[22] Marx, K. (1978). Capital. Vol. I. Penguin, Harmondsworth.

[23] Michels, R. (1915). Political Parties: A Sociological Study of the Oligarchical Tendenc - Ies of Modern Democracy. Translated into English by Eden Paul and Cedar Paul. New York: The Free Press. From the 1911 German source.

[24] Mills, C. Wright. (1956). The Power Elite. New York: Oxford University Press.

[25] Mosca, G. (1939). The Ruling Class. McGraw-Hill: New York.

[26] Moses, A. A, \& Olalekan, A. A, (2010) The Role and Impact of Non-Academics Staff Union (NASU) in Two Nigerian Universities, Library Philosophy and Practice 2010, ISSN 1522-0222.

[27] Ndagi, J (1999) Essentials of research methodology for educators" University press plc, Ibadan.

[28] Nchuchuwe, F. \& Ajulor, O. N. (2008) The Roles of Trade Unions and Civil Society in Good Governance: The case of Nigeria from 1999 Till Date. Nigeria Labour Congress Policy Document, 2007.

[29] National Universities Commission (2004) Recent development in private higher Education in Africa: Highlights of UNESCO, $A D E A$, and AAU Policy forum, Accra, Nov. 2-4 Vol 3 (45).

[30] Offiong, D. A. (1983). Organised Labour and Political Development in Nigeria. Calabar Centaur Press.

[31] Okoro, N. P \& Okoro, E, O. (2014) Time and Change: Development of Private Universities in Nigeria, International Journal of Business and Social Science Vol. 5, No. 9; August 2014, pp186-192.

[32] Okwori, A. \& Okwori, A. G. (2007). "Federal Character and Geographical Spread of Universities: Implications for Quality and Access to University Education in Nigeria" in J.B. Babalola, (eds.).

[33] Otobo, D. (1986). Foreign Interests and Nigerian Trade Unions. Ibadan: Heinemann Educational Books (Nig) Ltd.

[34] Omolayole, M. O. (1977, October). The Likely Impact of
Industrial Unionism on Industrial Relations Practice in Nigeria. Journal of the Institute of Personnel Management in Nigeria,4, p17.

[35] Orji, M. G (2010) Impact of Privatization on Employee job performance in Indorama-Eleme Petrochemical Company Ltd' MSc Thesis, Department of Business Administration, Igbinedion University Okada, Edo State Nigeria.

[36] Osang, W. (2002). The trade unions and their impact on university education in Nigeria. M.Ed. Thesis, Department of Adult Education University of Ibadan.

[37] Oyelere, M. A. (2007) Democratisation and democratic leadership: any prospect for trade union revitalisationin Nigeria?

learning.londonmet.ac.uk/wlri/jist2007/10\%20Syndicalisme/Z XOyelere.doc

[38] Oyelere, M \& Owoyemi, O. (2011) “Any Prospect for Trade Union Revitalisation in Nigeria through Democratisation and Democratic Leadership?" Journal of Politics and Law Vol. 4, No. 1.

[39] Pareto, V. (1935). The Mind and Society( Trattato Di Sosiologia Generale), Harcourt Brace.

[40] Pitan, O. O (2013) Role Of Unions In Industrial Relations: The Guidance Counsellor's Input. International Journal of Humanities and Social Science Invention' www.ijhssi.org Volume 2 Issue 10\| October.PP.52-57.

[41] Sonubi, O., M (1987), Readings in Industrial Relations in Nigeria.

[42] Utulu, C. C. (2001): "Quality of University Education in Nigeria: Problems and Solutions". Journal of the Common Wealth Council for Educational Administration and Management. 29 (1).

[43] Varghese, N. V. (2004a): Patterns in Ownership and Operation of Private Higher Education institutions, in N. V. Varghese (ed.) Private Higher Education, Paris. 11EP. Varghese.

[44] Weber, M. (1947). The Theory of Social and Economic Organizations. Henderson and Talcott Parsons, NY.

[45] World Bank, (2002): Constructing Knowledge Societies: New Challenge for Higher Education. Washington, D. C. World Bank. 